\title{
Mentorship Programs for Teacher Development in Soweto Schools
}

\author{
Dr Thulani E Mhlongo, PhD \\ University of Johannesburg \\ South African Council of Educators \\ South Africa
}

\begin{abstract}
This research report presents the findings important to continually create and maintain contexts for effective management framework in place to develop and manage teacher development through mentorship activities. It is rather a serious concern that, neither in the Soweto Circuit of the Gauteng Provincial Department of Education or any other province of South Africa are the best practices for teacher learning and development. Furthermore, the study reveals that ineffective and old traditional teacher supervisory models and methods are being employed in the selected schools within the Soweto Circuit of the Gauteng Provincial Department of Education especially because there is or benchmarks for developing and managing teacher development through mentorship programs. The primary aim of this research project is to develop an appropriate management policy framework based on the development and management of teacher development activities through mentorship programs, especially because this is one of the major challenges facing schools and educational organizations' today, and in general and more specifically for the Gauteng Provincial Education Department,for continuous school based teacher development especially the novice teachers in the selected adaptive schools of Soweto.The most appropriate method used was the case study through qualitative method; therefore this means that this research is of an exploratory nature. Focus group interviews were utilized as a research method. Department of Education officials; school principals, Head of Departments and teachers as representatives participated in the focus group interviews and they have all been involved and have experience in the teaching field and some of them have experience in the old traditional teacher supervisory and related teacher development methods. All the focus group interviews were based on the original research question namely: "How should teacher development through mentorship programs be developed and managed to ensure the success of such programs and related activities?"
\end{abstract}

Keywords: Mentorship programs, teacher development, reflective educators.

\section{Introduction and rationale}

A major issue in human resource management for any middle level developing country is a question of employee development especially within the educational structure and system. There is a large literature for advanced countries' as far as the human resource development and management within the education sector is concerned, but this is a neglected topic for poor countries' therefore this research seek to make a contribution in this regard. People at all levels are the essence of an organization and their full development enables innovation and creativity in furthering the organization's objectives especially the adapting educational organizations. The above sentiments are also supported by the South African Council of Educators Act 31 of 2000, as it advocates and supports teacher development by acknowledging that teachers have a professional obligation towards the education, and induction into the profession, of new members of the teaching profession (SACE, section (E-17) 7.5.2000). This standpoint is also supported by the National Policy Framework for Teacher Education and Development in South Africa (2006:16-22), that likewise emphasized the continuing professional training and development of teachers. According to Reviews of National Policies for Education-South Africa (2008: 8-9), South African Council of Educators (SACE) as the professional council need to enhance the status of the teaching profession and promote the development of educators and their professional conduct. According to (O'Donnell et al. 2006) teacher development through mentorship has emerged as a complex diverse field serving many areas with purposes. This multiplicity of purposes has led to questioning about the nature of human resource development process in education whether it is concerned with the development of "educators" for the benefit of individuals and for the benefit of the organizations concerned.

\section{Statement of the problem and motivation}

Mentorship in Schools within the Soweto circuit of the Gauteng Province has become a controversial issue because of the outdated traditional mentorship supervision system, especially amongst novice educators. Such educators are reluctant to execute their duties, as evident in them not having the opportunity to reflect on their own teaching, and thus gaining constructive feedback on it. 
This includes leadership roles, learning outcomes and school effectiveness being recognized and developed with support from colleagues who are themselves reflective practitioners (Harrison, 2004: 150). Nor are they are provided with a mentorship induction program consisting of a forum that would provide regular observation and feedback, and thus experiencing peer mentorship, and that would create opportunities to work and talk with other teachers during mentor training activities.

The implication of the above statement for the education system as a whole, and more specifically for the development of educators and management of an effective education system is profound. Furthermore, it is in line with experience and research, especially in developing countries, that indicates top-down systems in the area of educator development and educational management continually leave its actual form in individual schools virtually untouched (Fullan, 1991:1; National Department of Education, 1996:14; Shaeffer, 1997:223). The researcher argues that the abovementioned problems emanate from a number of factors, such as lack of mentors to communicate and implement such programs, coupled with a lack of motivation and resources, especially trained teacher mentors.

According to Blair and Bercik (1987:64), teacher mentors are essential to successful induction. They declared that in order to achieve success, effective education process through reflective educators need strong support at all levels (national, provincial, district, and within the school). Meanwhile, Crawley et al. (1995:127) assert that teacher development through mentorship not only develops teachers but also plays a vital role in the school management processes, as the key to effective management of education especially its human resources. Since projects for school improvement were often managed by the third sector (NGOs and intermediary agencies), it is important to built and facilitate management capacity and the capacity of educators by continuously developing an educational management framework for an effective education system (Udelhofen \& Larson, 2003:10).

However, the legacy of apartheid in the field of teacher development and educational management specifically is wellknown, and has left most of the schools in the country, especially historically disadvantaged ones, with an ineffective system of teacher development and educational management, coupled with inefficient management and utilization of resources (financial, material and human resources) (Hofmeyer, 1990:1-3; McLennan, 1997:25; National Department of Education,1996:17-20; National Education Policy Act, RSA, 1996a).

\section{Research questions}

In light of the context of this study and the problem statement, this study raises the following questions:

.What is the meaning of teacher development through mentorship programs?

.What role does the Gauteng Provincial Department of Education play in the development of its teachers?

.What role can be played by the management in the development of teachers through Mentorship?

.How teacher development through mentorship activities can be developed and managed effectively?

\section{Aim of the report}

The main aim of the study was to research how the Soweto Schools can develop, and manage teacher development activities through mentorship programs, for continuous school based teacher development, especially the novice teachers in the selected adaptive schools of Soweto.

\section{Significance of the report}

The background to the research problem outlined above points to the need for educator development through mentorship and induction process, in order to provide reflective, quality teaching experiences. Educational institutions can, by this means, become viable environments for collaborative teaching and learning where educators collaborate, understand and also enjoy what they do.

\section{Research design and methodology}

In this study the researcher attempts to understand and explain the challenges of mentorship in selected Schools in Soweto. In order to achieve this objective, qualitative and descriptive research approach was employed. The aim of the qualitative research is to gain insight into the meanings that participants give to their reality (Merriam, 1998:46). In the first phase in revealing the challenges facing educators in implementing the mentorship and induction programs, coupled by highlighting the implications of mentorship and induction programs is envisaged. In the second phase, defining and developing contextual strategies and policies to improve the implementation and effectiveness of the mentorship and induction programs was facilitated. This insight was gained by obtaining detailed descriptions within certain contexts, because the researcher is an observer and participant. Researchers interact with those they study, whether this interaction assumes the form of living with or observing informants over a prolonged period of time, or actual collaboration (Creswell, 1994:6). 
According to Merriam (1998:5) qualitative research is an umbrella concept covering several forms of inquiry, in this instance the single case study of seven selected Soweto schools as it assisted the researcher to understand and explain the meaning of social phenomena with as little disruption of the selected Soweto schools as possible. In the process, the researcher is able to grasp the subjective meanings of social action during the process of continuous school based mentorship for teacher development within the selected Soweto schools

\section{Research paradigm}

Through this enquiry, the researcher was operating within the interpretivist-constructivist paradigm (Biehler \& Snowmann, 2003: 301; Lincoln \& Guba, 2004:32). Interpretivism is an epistemology that advocates that, it is necessary for the researcher to understand differences between humans in our role as social actors. Crucial to the interpretivist epistemology is that the researcher has to adopt an empathetic stance, because the challenge here is to enter the social world of our research subjects and understand their world from their point of view (Saunders et al., 2007:103) A qualitative research approach entailing a generic phenomenological enquiry guided this study (Andronovich \& Riposa, 1993:4; Marshall \& Rossman, 1995:76).

\section{Population and sampling}

With regard to the sample and the population in this study, the purposive sampling was applied (Henning, Van Rensburg \& Smit, 2004:71;Berg, 2004:35) which allowed the researcher to conduct research in a field (the selected schools in Soweto) that by design aim at the educators especially the senior educators including district officials population. The richest data can be converged (Merriam, 1998:61) from educators who have experience and those with no experience in mentorship activities. Such purposive sampling makes full use of the flexibility needed for such study. The researcher therefore had to take care in selecting a sample which is representative of the population in which the social phenomenon takes place, as the population might be too big (Mouton \& Marais, 1994:67 and Leedy, 1997:197199).The sample population therefore display all the characteristics and attributes of the total population (Oppenheim, 1996:38).The setting of this research report was restricted to seven (7) Schools, in the Soweto Circuit of the Gauteng Province. A purposive sample of five (5) educators from each participating school was selected. This process provided the researcher with thirty five (35) educators. Secondly, of the thirty five (35) educator participants, specific educator participants (one per school) were selected for richer provision of data. Thirdly, the senior educators especially the principals of each of the educator participants as well as the Head of Departments of specific areas of learning were asked to participate in the research. Finally, two district officials from the Soweto Circuit were also interviewed.

\section{Data collection}

The data collection process for this investigation was based on semi-structured interviews, for individuals and focus group interviews. Again individual and semi-structured focus group interview process is vital because this type of data gathering is aimed at gathering real experiences of the social actors during the process of school based teacher development activities (Mouton, 2008:105). It is imperative to further indicate that, participants and non-participants observations was facilitated in this regard (observer as participant and complete observer) especially for main actors (educators, district personnel's and policy makers) as it was applied in this study. Again the process also allowed a single case study method based on; (a) examination of individuals, groups or schools, educator participant completion of questionnaires, (b) documents analysis and review (policies and results), such as mentorship and induction records, literature, reports by educator mentors and or consultant educator mentor specialists pertaining to educator mentee participants, (c)completion of a senior educator interviews, (d) specific educator participants interviews, (e) educator participants interviews and interviews with district officials. Data collection and data analysis are viewed as interrelated and interdependent process (Strauss \& Corbin, 1990:59).

\section{A single case study}

The focus was on seven schools which enabled the researcher to compare and describe these different schools to provide an insight into mentorship of educators in schools. According to Creswell (2008:477) the researcher seeks to develop an in-depth understanding of the mentorship programs for teacher development through the facilitation of the process of the development and management of mentorship programs by collecting multiple forms of data. The case study was located within their larger context geographically, politically, socially and economically. The case study was informed by the understanding of the subjective meanings of social actors (senior educators and ordinary educators), (How individuals make sense of their world). Therefore, it lends itself to an inductive method and a phenomenological approach to investigation, data analysis and development of a conceptual framework for exploring mentorship of educators. 


\section{Document analysis and review}

Official documents produced by schools provide a valuable source of information, (Henning et al., 2005:99) and did offer a researcher an unobtrusive record of participant's behavior including the concerned schools process and procedures in developing and managing mentorship programs as a strategy for teacher development. Document Review, such as public documents, newspapers, minutes of meetings enables a researcher to obtain the language and words of informants. Documents was obtained at a time convenient to the researcher, again as an unobtrusive source of information; document review represents data that are thoughtful in that informants have given attention to compiling a research report. As written evidence, it saves a researchers time and expense of transcribing (Creswell, 1994:151).

\section{Measures to ensure trustworthiness}

Trustworthiness as far as this research report is concerned, refers to the quality of the research findings. Trustworthiness asks in which way the researcher or any other reader judge the quality of the research findings (Miles \& Huberman, 1994:277). According to (Lincolin; 1992:71; Lincolin \& Guba 1985:290-305), the criteria that reflect the trustworthiness of qualitative research paradigm include; credibility, transferability, dependability and conformability. The ultimate aim of all science is the search of honesty "(Mouton, 2001:239). As part of the research process, honesty was established through ensuring that credibility and accuracy of the research process, was ascertained in as much as the trustworthiness of any research is paramount to its success (Strauss \& Myburgh, 2003:59).Firstly, credibility was established in this research process through a rich description of educator experiences of mentorship.

\section{Literature review based on the mentorship programs for teacher development}

A mentorship programs for teacher development is needed by the Soweto circuit of the Gauteng Department of Education (GDE), especially as an effective strategy for teacher development, because it involves a range of education stakeholders as partners, including private sector organizations, school communities, public sector organizations and civil society (Dean, 1991:13; Villani, 2002:36). According to Fletcher (2000:2), mentoring is about whole school and whole higher education institution and school management, development and effective facilitation of partnerships. Mentorship programs for teacher development as a strategy for teacher development aim at fostering quality education and teaching, especially if shared through reflective practices and collectively (Middleton et al., 2000:43). The researcher argues that these strategies are for educator development and in the process form part of whole school management Villani (2002:35) stated that mentorship was not simply a "loose collaboration" between two parties, a "mediation or negotiation" between organizations or "a dialogue" between two parties for the sole purpose of "information sharing". Such simplistic views of mentorship would only lead to the distortion of what it really means.

It is clear from the literature, both national and international, that mentorship programs for teacher development and as a strategy for educator development need to be underpinned by philosophical, ethical and practical implications of the mentorship process (Brooks \& Sikes, 1997:6; Fletcher, 2000:5). Throughout South Africa, educational systems have begun to realize that a serious problem exists when teachers call for assistance and guidance, especially during their early years in the profession. No matter how prepared, a teacher needs someone to turn to with the inevitable questions and problems that arise as he/she enters the profession. From the international literature a mentorship programs for teacher development may be defined as an effective strategy for teacher development, and a professional obligation based on agreement between two or more parties who agree to cooperatively work towards shared and/or compatible objectives. According to Brooks \& Sikes (1997:17-21), these mentorship objectives comprise the following:

Shared values, objectives, roles for and responsibility and management of the work

- Collaboration on common causes and outcomes

- Mutually beneficial relations based on win-win situations

- Understanding of standards based on quality education process

- Sensitivity to the needs of the fellow colleague especially the novice teacher

- Ability to transmit effective teaching strategies

- Ability to listen, support and communicate openly and effectively

- Understanding of diverse teaching styles and modeling of continuous learning

- Restraint from judgment

Accountability and joint investment of resources based on time, material, expertise, information and knowledge and managing teacher development. Based on ethical and professional obligations, an effective mentorship process is also guided by operational professional principles as suggested by Dean (1991:123) and Villani (2002:37): 
- Strive to create an environment of trust and loyalty

- Believe that all teachers are capable of development and change

- Remain positive and optimistic

Delegate responsible wherever possible in terms of the above mentorship objectives, mentorship can be regarded as a form of collaboration between different stakeholders and partners in education, with an emphasis on mutually beneficial relationships. Mentorship programs also assist in the facilitation of the process of developing and encourage staff to become involved in educational issues, curriculum change and implementation, further;

- Provide support and counseling for individual teachers

- Encourage open dialogue between all members and provide praise and encouragement for constructive feedback to help teachers develop a critical approach to their work

- Provide opportunities for increased job satisfaction and develop a wider range of skills

For the purpose of this research, mentorship programs for teacher development as a strategy for teacher development are defined as a mutual educational supportive process and strategic professional union within an educational context that is informed by formal agreement, and in which all members as colleagues commit themselves to working together to develop collaborative, systemic and productive relationships within their work environment. This will be based on integrity, honesty, trust, and respect. Such a supportive process helps teachers become reflective practitioners, supported by integrated and sustainable strategies that enhance the human resources potential of learners in schools and their communities (Borman, 1996:10-11). Based on the above definition, and through careful analysis of the literature, certain common characteristics of partnership emerge. An effective mentorship process requires a structure to steer the implementation of the mentoring strategy, especially because the support structure can take various forms, depending on the unique nature of the organization (Meyer \& Fourie, 2004:185-186). The researcher reasons that, for a mentorship process to be effective, its structure must connect with all parties and be supported by all levels of the organization, especially the leadership. However, this does not mean that a new structure, hierarchy and bureaucracy is created, but rather that there is an efficient developing and managing of the programs an effective strategy for educator development (Fletcher, 2000:22). From the literature, the following components are important for developing and managing mentorship Programs:

- A policy statement on mentorship process

- The formulation of a mentoring strategy

- Assigning a mentoring steering committee

- Appointing mentoring coordinators

- Allocation of resources for mentorship activities

- Communication and execution plan for mentorship process.

- Senior management including a governing body should be involved.

- Top-level endorsement from all parts of the system should be involved the school governing body including district managers.

- Designated personnel from all the above each partners need to participate in policy development.

- Designated personnel from all the above each partners need to work in groups and in action teams.

- A system of ongoing information sharing based on new trends, documentation, research and Analysis should be facilitated.

A formal contract agreement document outlining the time span and general terms and conditions of the mentorship relationship should be developed (Keyserlingk et al., 1997:245-246; Meyer \& Fourie, 2004:186).A formalized system could also foster decision-making based on relevant activities, such as keeping track of completed activities, allocation of resources, and developing relevant activities (Watson \& Fullan, 1993:216). Such a formal relationship would be characterized by a shared mission and vision, shared challenges or concerns, mutual benefit, shared responsibilities, equality in developing initiatives, and shared governance. This would increase the space and chance for mentorship programs to make an impact on quality education, especially management of education. The emphasis in teaching tends to be on caring for learners rather than for teachers within the school, yet it is essential that the teachers develop in their work if learners are to achieve their potential. South Africa is in a period of unprecedented change, of which teacher development is part, particularly teaching style. According to Zachary (2000:36), in many respects teachers have moved a long way in a short time in accommodating themselves to the changes, but there are nevertheless many constraints which affect their readiness and ability to change which must be taken into account in planning professional development through a mentorship process. Blair \& Bercik (1987:145) further suggest that mentors need training for effective planning for professional development, as this will assist teachers in demonstrating and observing teaching, and coaching other teachers. They should also continuously study teacher development, new teacher needs, effective 
teaching, supervision skills and professional development. Perhaps more important than having a mere structure in place is that developing and managing mentorship programs have to be guided by process and procedures. This is vital because mentorship has to be geared to teachers developing their profession. If teachers have "come of age" in developed countries, it is evident from the literature that those in South Africa and other developing countries are still "in their infancy" (Ministerial Committee on Education, 2005:12). There is a range of opinions about whether the ideal relationship as far as the mentorship is concerned should be symbiotic, synergistic, collaborative, independent and reciprocal, commitment-driven or purposeful (Keyserlingk et al., 997:246). Crawley et al. (1995:125) assert that it is only through empathetic and professional development that teachers can both deliver their best performances as teachers and become contributing members of a developing professional community. Professional development through mentorship may be guided by the following:

- Practice supported by theory

- Responsibility for admission of members

- A long period of training

- Code of ethics governing behavior

A high degree of autonomy requires common objectives, which keep the teachers focused on issues that are mutually beneficial and add value and create synergy between their common activities. Commitment should develop trust, respect and ownership within the relationship, with teachers dedicating time and resources to ensure that the mentorship process is sustainable. Learning and sharing is vital as to ensure a continuous revitalization of mentorship activities, where teachers learn and share each other's experience, knowledge, expertise and ideas. Good mentors will develop teachers to their full potential, especially when they are prepared to play a leadership role in promoting mentorship as the vital need for professional development of teachers. This is important because at the same time the process of building capacity amongst the teachers who are dedicated to their professional development, and thus will contribute to systemic change. According to Kerry and Mayes (1995:38), all the above aspects ultimately contribute to the cultivation and maintenance of the relationships among teachers, and are equally important to the development and management of mentorship programs for teacher development. Bell and Gilbert (1996:161) suggest further that, through mentorship activities, professional development as part of teacher development involves not only the use of new teaching activities in the classroom but also the development of the beliefs and conceptions underlying the actions. Clarification of core values and commitments is important in this regard and, more especially, for the development of moral frameworks in education through mentorship programs for teacher development. According to Zachary (2000:36), in many respects teachers have moved a long way in a short time in accommodating themselves to the changes, but there are nevertheless many constraints which affect their readiness and ability to change which must be taken into account in planning professional development through a mentorship process. Blair \& Bercik (1987:145) further suggest that mentors need training for effective planning for professional development, as this will assist teachers in demonstrating and observing teaching, and coaching other teachers. They should also continuously study teacher development, new teacher needs, effective teaching, supervision skills and professional development.

\section{Recommendations}

In light of the above research, the recommendations are as follows: It is recommended that all stakeholders ensure that they create awareness amongst potential members (teachers), to ensure ownership and buy-in from all potential partners, and in the process develop common interests and values amongst stakeholders and mutual benefits, as well as ensuring legitimacy for teacher development through mentorship programs. It is also recommended that a two-way communication strategy is developed to ensure continuous interaction between beneficiaries and or stakeholders. It is strongly recommended that beneficiaries be empowered and capacitated to ensure that mentorship programs are sustainable long after the planned teacher development activities have come to an end. Based on the above, the following are the main recommendation points to be considered during the management of mentorship programs for teacher development:

.That the teacher development activities through mentorship programs management framework be adapted and implemented in a suitable manner for the purpose of consistent teacher development processes.

.That they be managed in a structured and systematic manner to ensure effectiveness and efficiency of teacher development through mentorship process.

.That the GDE and their districts capacitate those officials tasked to manage mentorship programs for teacher development. 


\section{Limitations and recommendations for future research}

The first issue is that the selected schools are in the vicinity of the black African community in Soweto, an old Township situated within the west area of the Gauteng Province. They are selected as a sample of all schools in Soweto. This will pose the problem of generalization of the findings. Secondly, another issue is that all teachers are black and come from the same environment and surrounding areas in Soweto. Teachers in this area are very disadvantaged and lack resources; hence plans to develop their professional skills are necessary. Finally, the fact that teachers need ongoing professional development necessitates that this must become part of the core mission of the Provincial Department of Education. Since the schools were selected as a sample of schools only in Soweto this will pose the problem of generalization of the findings. As a qualitative study, the findings could be subject to other interpretations within the human resource development field. Through the research methods used, especially the case study, this study will not be generalizable to all areas of the educational organizations. Guba and Lincoln (1981, cited in Merriam, 1998:207) pointed out that qualitative studies may be problematic for qualitative investigators because: "In Qualitative research, a single case or small random sample is selected precisely because the researcher wishes to understand the particular in-depth, not to find out what is generally true of the many". The following further research recommendations can be made:

-That a further study be made of how the national and provincial Departments of Education and their relevant Districts, as the vehicles to deliver the teacher development programs and related activities in the various provinces, operate and execute such activities and in the process compare them to each other.

- That further study is initiated on how various agencies, trusts, NGOs and independent professional teacher development agencies in the various provinces develop a comprehensive management framework for managing teacher development through mentorship programs.

\section{Conclusion}

This research endeavors to develop a management framework based on the mentorship programs for teacher development, that is informed by the process of developing and managing mentorship programs as a strategy for teacher development in selected schools in Soweto, as the effective strategy for teacher development and management in education in the hope that such a management framework could assist educators at large especially the Department of Education in a practical way to achieve the aims and objectives of teacher development and educational management programs. It could be argued that the systems approach to the management of mentorship programs for teacher development, and as the effective strategy for teacher development and management in education would be particularly relevant to the South African context. Development and management of mentorship programs in South African educational institutions are currently in their infancy. It is therefore imperative to develop a thorough understanding of such programs for effective also continuous development of teachers and management of education. Mentorship programs for teacher development that is informed by and based on the process of developing and managing mentorship activities can never be seen as the remedy for all the problems inherent in the education system both internationally and locally. It would be naïve and dishonest to suggest otherwise. However, mentorship programs for teacher development, based on the process of developing and managing mentorship activities, do allow like-minded individuals and educational organizations, including the concerned communities, to collaborate and make a synergistic impact on, and a holistic approach to, educational transformation. Indeed it is evident from this chapter that teacher development adds value to the quality of education and education transformation in South Africa, by:

- Addressing the real issues of access, redress, equity and quality in education

- Contributing to the curriculum as well as the relevance and quality of lifelong learning

- Effectively utilizing and maximizing teaching and learning resources in the community to make schools more efficient

- Empowering learners to actively participate as citizens in the political, social, economic and cultural life of the concerned communities

- Bringing together government, civil society, including other relevant organizations and communities to work collaboratively to address the problems and challenges within the education system.

Mentorship programs for teacher development based on the process of the development and management of mentorship programs as an effective strategy for teacher development is always a work in progress and which moves all members, groups and stakeholders into action where all planned activities are implemented accordingly.Mentorship programs for teacher development through effective process of developing and managing mentorship programs is key to, and most challenging aspect of, an effective and vital process of teacher development needed by schools and educational organizations. 


\section{References}

Andronovich, G. D. \&Riposa, G. 1993. Doing Urban Research. USA. Sage Publications.

Bell, C. 1996. Managers as mentors: Building Partnership for Learning. San Francisco: Berrett-Koehler.

Bell, L \& C. Day, 1991. Managing the Professional Development of Teachers: Developing Teachers and Teaching.Open University Press-Buckingham, London.

Brooks, V. and Sikes, P. 1997. The Good Mentor Guide.Initial Teacher Education in Secondary Schools.Open University Press. Buckingham. Philadelphia.

Creswell, J. W. 1994. Research design in qualitative approaches. Thousand Oaks: Sage.

Creswell, J. W. 1998. Qualitative Inquiry and Research Design. London: Sage.

Creswell, J. W. 2003. Research Design. Qualitative, Quantitative, and mixed methods approach. Second Edition: London: Sage.

Dean, J. 1991. Professional Development in School; Developing Teachers and Teaching.Open University PressBuckingham, London.

Denzin, N. K. \& Lincoln, Y. S. 1994.Handbook of qualitative research. Thousand Oaks: Sage Publications.

Education Sectoral Review Team: Learning from good practices in Africa; Annual Survey Report of the

Ferreira, M 1988: A sociological analysis of medical encounters of aged persons at an outpatient centre: A qualitative approach. (In: Ferreira, M \& Mouton, J eds. 1988: Introduction to Qualitative Research Methods. Module 3 Pretoria: Human Sciences Research Council, pp. 102-129).

Ferreira, M \& Mouton, J 1989: An introduction to qualitative methods. Module 3. Pretoria: Human Science Research Council.

Ferreira, M \&Puth, G 1988: Focus group interviews. (In: Ferreira, M \& Mouton, J eds. 1988 Introduction to qualitative research methods. Module 3 Pretoria. HSRC, pp. 162-189).

Fields, J. C. 1993. Total quality for schools: A suggestion for American education. Wisconsin: ASQC.

Fletcher, S. 2000. Mentoring in Schools: A Handbook of Good Practice; Kogan Page Limited-London UK.

Guba, EG 1981: The paradigm dialogue, Newbury Park. Sage Publications.

Harrington, C. C \& Boardman, S. K. 1997.Paths to success.Beating the odds in American society. Cambridge: Massachusetts, Harvard University.

Harrison, R. (2004) People and Organizations: Employee Development. The

Cromwell Press, Wiltshire.

Henning, E., van Rensburg, W. and Smit, B. (2004). Finding your way in qualitative Research. Van Schaik: Pretoria.

Hustler, D. and McINTYRE, D. 1996.Developing Competent Teachers: Approaches to Professional Competence in Teacher Education.

Kerry, T. \& Mayes, S. 1995. Issues in Mentoring. The Open University: Routledge, London-Great Britain.

Keyserlingik, RP; PA \& Peter, P 1997: Lessons learned from partnership and networks in education. (In: Smith, WJ; Thurlow, M \& Foster, WF eds. 1997: Supporting education management in South Africa - international perspectives. Johannesburg: South Africa, pp. 235-266). Khoza, 2009:19).

Krefting, L. 1991. Rigor in qualitative research.The assessment of trustworthiness. The American journal of occupational therapy, 45 (3):214-222.

Kvale, S. 1983: The qualitative research interview: a phenomenological and hermeneutical mode of understanding. Journal of Phenomenological Psychology, 14 March 1983: 171-196.

Leedy, PD. 1997: Practical research planning and design New Jersey: Prentice Hall.

Leopold, J. Harris, L. and Watson, T. (2005) The Strategic Management of Human Resources. Prentice Hall.

Lincoln, Y.S. \&Guba, E.G. 1985: Naturalistic inquiry. Beverly Hills: Sage Publications.

Lincoln, Y.S. 1995. Emerging Criteria for Quality in Qualitative and Interpretive Research. Qualitative Inquiry, Volume 1 Number 3, 1995 275-289. Sage Publications Inc.

Marshall, C. \&Rossman, B. 1995.Designing qualitative research. London: Sage.

Marson, J. 1987. Who supports the mentor? Australian journal of guidance and mentorship, I (nd): 1-60.

Mason, J. 1996. Qualitative research. London: Sage.

Maykut, P. J. \& Morehouse, and R. 1994: Beginning qualitative research: A philosophical and practical guide. London: Biddlers.

McLennan, A. 1997: Education management development: Trends and frameworks. (In: Smith, W.J; Thurlow, M \& Foster, W.F eds. 1997: Supporting education management in South Africa - International perspectives. Johannesburg: South Africa, pp. 22-68).

McLeod, J. (2007). Qualitative Research in Counseling and Psychotherapy. London: Sage. 
Merriam, S.B. 1988: Case Study Research in Education: A Qualitative Approach. San Francisco: Jossey BassPublishers.

Merriam, S.B. 1991: Case Study Research in Education: A Qualitative Approach. San Francisco: Jossey BassPublishers.

Merriam, S. B. 1998. Qualitative Research and Case Study Applications in Education. San Francisco: Jossey-Bass.

Meyer, M. \&Fourie, L. 2004. Mentoring and coaching. South Africa: Knowres Publishing.

Meyer, S. 1997: Notes on partnership in education. National Business Initiative. Auckland Park: Edupol October 1997.

Middleton, V. 2000.A community of learners.Educational leadership, 57 (8) 51-53.

Miles, MB \&Huberman, AM 1994: Qualitative data analysis. Second edition. London: Sage Publications.

Mouton, J. 1996.Understanding social research. Pretoria: J. L. Van Schaik.

Mouton, J. \& Marais, H. C. 1994.Basic concepts in the methodology of the social sciences. Pretoria: Human Sciences Research Council Publishers.

Mouton, J. (2001).How to succeed in your Master's and Doctoral Studies.A South African Guide and Resource Book. Van Schaik Publishers: Pretoria.

National Department of Education, 1996: Changing management to manage change in education. Report of the Task Team on Education Management Development. Pretoria: Department of Education South Africa. CTP Book Printers.

National Policy Framework. 2006. Teacher Education and Development in South Africa. Pretoria. Government Printers.

O'Donnell, D. (2006),'Theory and method on intellectual capital creation: addressing communicative action through relative methods', Journal of Intellectual capital, 5, 2, 294-311.

Oppenheim, AN. 1996: Questionnaire design, interviewing and attitude measurement. London: Printer Publishers.

Republic of South Africa, 1996a: National Education Policy Act (Act of 1996). Pretoria. Government Printers.

Republic of South Africa, 1996b: South African Schools Act 1996. (Act of No 84 of 1996). Pretoria. Government Printers.

Republic of South Africa, 1998a: White Paper on Transformation of Education and Training, 1998. Pretoria. Government Printers.

Republic of South Africa, 1998b: Further Education and Training Act (Act of No 98 of 1998). Pretoria. Government Printers.

Republic of South Africa, 1998c: Report of the Education Sectoral Review Team. Pretoria. Government Printers. Republic of South Africa, 1999a: The President Education Initiative Research Project. Pretoria. Government Printers. Republic of South Africa, 2000: Tirisano-Quality Education for All, 2000. Pretoria. Government Printers.

Republic of South Africa, 2005a: Report on the Ministerial Committee on Rural Education. Pretoria. Government Printers.

Republic of South Africa, 2007a: Minister of Education's, Report on; National Policy Framework for Teacher Education and Development (NPFTED)

Republic of South Africa, 2008a: Review of National Policies for Education in South Africa. Pretoria. Government Printers.

Saunders, M., Lewis, P., and Thorn hill, A. 2007.Research methods for business students. 4th ed., London: Pitman.

Schumarker, S. \& McMillan, J. H. 1993. Research in education: A conceptual introduction. Third edition. New York: Harper Press.

Senge. P. 1990: The fifth discipline: The art and practice of the learning organization. London: Century Press.

Shaeffer, S. 1997: Supporting local school management: The key to successful education reform. (In: W J; Thurlow, M \& Foster, WF eds. 1997: Supporting education management in South Africa - International perspectives. Johannesburg: South Africa, pp. 223-232).

Smith, S. C. \&Pielle. 1996. School leadership. New York: Library of congress cataloguing in Publication Data.

Strauss, A. \& Corbin, J. 1990: Basics of qualitative research. Grounded theory procedures and techniques.Fifth edition. Newbury Park: Sage Publications.

Sylverman, D. 1997. Qualitative research: Theory, method and practice. London: Sage.

Smyth, J. 1991. Problem in teaching through a critical approach to clinical supervision. Curriculum Inquiry, 21 (3): 321-349.

South African Council of Educators, Act 31 of 2000.Pretoria. Government Printers.

South African Council of Educators and Department of Education, 2008.Research Journal on Continuing Professional Teacher Development Practices in Schools. Pretoria. Government Printers.

South African Council of Educators, 2007.Towards Excellence in Education; CPTD Task Team Endorsement Handbook. Pretoria. 
South African National Education Policy Act 27 of 1996. Pretoria. Government Printers.

Stone, B. W. 1987. The nature of management. Wokingham: Van Nostrand Reinhold co.

Strauss, A. \& Corbin, J. 1990.Basics of qualitative research.Grounded theory procedures and techniques. California: Sage.

Udelhofen, S. \& Larson, K. 2003.The mentoring year.Carwin Press, Inc. London: Sage.

Van Balkom, W; Ngcongo, R. \&Steenbergh, D 1998: Education reform in South Africa: Challenges, adversaries and considerations International Journal of Educational Reform 7 (2), April 1998: 142-149.

Villani, S. 2002. Mentoring Programs for New Teachers.Models of Induction and Support. Corwin Press, Inc. Thousand Oaks, California.

Watson, N. \&Fullan, MG. 1993: Beyond school district - University partnership. (In: Fullan, MG. \& Hargreaves, eds. 1993: A teacher development and educational change). London: The Falmer Press.

Zachary, L.2000. The Mentor's Guide: Facilitating Effective Learning Relationships. Jossey-Bass.A Wiley Company. San Francisco. 